\title{
Applying Rhizobacteria on Maize Cultivation in Northern Benin: Effect on Growth and Yield
}

\author{
Olaréwadjou Amogou${ }^{1}$, Gustave Dagbénonbakin'2, Nadège Adoukè Agbodjato1, \\ Pacôme Agossou Noumavo ${ }^{1,3}$, Kolawolé Valère Salako4, Marcel Yévèdo Adoko', \\ Romain Glèlè Kakaï ${ }^{4}$, Adolphe Adjanohoun ${ }^{2}$, Lamine Baba-Moussa ${ }^{*}$
}

\begin{abstract}
${ }^{1}$ Laboratoire de Biologie et de Typage Moléculaire en Microbiologie, Département de Biochimie et de Biologie Cellulaire/ Faculté des Sciences et Techniques/ Université d'Abomey-Calavi/05BP 1604 Cotonou, Bénin

${ }^{2}$ Centre de Recherches Agricoles d'Agonkanmey, Institut National des Recherches Agricoles du Bénin, Cotonou, Bénin

${ }^{3}$ Laboratoire de Microbiologie et des Technologies Alimentaires, Département de Biologie Végétale/ Faculté des Sciences et Techniques/ Université d'Abomey-Calavi/Cotonou, Bénin

${ }^{4}$ Laboratoire de Biomathématique et d'estimation forestière, Faculty of Agronomic Sciences, University of Abomey-Calavi, 04BP1525, Bénin

Email: *laminesaid@yahoo.fr
\end{abstract}

How to cite this paper: Amogou, O., Dagbénonbakin, G., Agbodjato, N.A., Noumavo, P.A., Salako, K.V., Adoko, M.Y., Kakaï, R.G., Adjanohoun, A. and Baba-Moussa, L. (2019) Applying Rhizobacteria on Maize Cultivation in Northern Benin: Effect on Growth and Yield. Agricultural Sciences, 10, 763-782.

https://doi.org/10.4236/as.2019.106059

Received: May 6, 2019

Accepted: June 18, 2019

Published: June 21, 2019

Copyright $\odot 2019$ by author(s) and Scientific Research Publishing Inc. This work is licensed under the Creative Commons Attribution International License (CC BY 4.0).

http://creativecommons.org/licenses/by/4.0/

Open Access

\begin{abstract}
The aim of the study was to investigate the effects of five plant growth-promoting rhizobacteria (PGPR) (Bacillus panthothenicus; Pseudomonas Cichorii; Pseudomonas Putida; Pseudomonas syringae and Serratia marcescens) on the growth and yield of maize on a ferruginous soil under field condition. Maize seeds were inoculated with $10 \mathrm{ml}$ of bacterial suspension. Study was conducted in a completely randomized design with fifteen treatments and three replicates. A half-dose of recommended $(13,17,17$ $\left.\mathrm{kg} \cdot \mathrm{ha}^{-1}\right)$ NPK was applied 15 days after emergence. The results show that the Serratia marcescens $+50 \%$ NPK treatment yielded the best results for height, fresh underground biomass, dry aboveground biomass, dry underground biomass, and grain yield with respective increases of $41.09 \%, 217.5 \%$, $213.34 \%, 93.82 \%$, and $39.05 \%$ compared to the control. Maximum stem diameter (increases of $49.65 \%$ ) was recorded in the plants treated with $100 \%$ NPK (full dose NPK) while the highest leaf area $\left(466.36 \pm 9.57 \mathrm{~cm}^{2}\right)$, obtained on plant treated with Pseudomonas putida $+50 \%$ NPK was $32.08 \%$ greater than in the non-inoculated control. Our results suggest the use of these rhizobacteria as biological fertilizers for enhancing the growth and maize seed yield in ferruginous soil in the North of Benin.
\end{abstract}

\section{Keywords}

Rhizobacteria PGPR, Ferruginous Soil, Corn, Growth, Yield 


\section{Introduction}

Maize (Zea mays L.), the basis of food in West Africa [1], occupies nearly 17\% of the few 200 million hectares sown [2]. In Benin, it is cultivated by $85 \%$ of households engaged in agriculture [3]. It is a strategic cultivation in terms of food security, economic profitability and constitutes for the Government of Benin the main speculation to intensify to achieve food self-sufficiency [4] [5]. Most of Benin's land and that of other countries in sub-Saharan Africa are in a state of advanced degradation and deficient in nutrients including nitrogen, phosphorus and potassium [6] [7]. The decline in agricultural productivity caused by the poverty of cultivated soils has led the extension services to set up a fertilization program every year which recommends the doses of $150 \mathrm{~kg} / \mathrm{ha}$ of NPK fertilizer (14-23-14) and $50 \mathrm{~kg} / \mathrm{ha}$ of urea for maize cultivation. The intensive use of mineral fertilizers further exposes crops to attacks by pathogenic microorganisms, resulting in soil acidification and in a decline in fertility. In addition, the deterioration of soil fertility is also related to the loss associated with beneficial microbial diversity for plants [8]. Several studies have also identified a relatively small response of crops for exclusive use and for the duration of mineral fertilizers [9] [10]. In this context, to feed the population of Benin, which, according to [11] should double every 20 years if the current trend continues, it would require very fertile soils for sustainable and environmentally-friendly agricultural production. The use of technologies that integrate beneficial soil microorganisms especially rhizobacteria promoters of vegetative growth of plants called Plant Growth Promoting Rhizobacteria (PGPR) represent a solution sustainable alternative to ensure long-term soil fertility and increase agricultural productivity [12]. Indeed, since their first description in 1978 by [13] the PGPR have particularly attracted the attention of scientists. These are soil bacteria that colonize the root surface and have beneficial effects on plant growth through the secretion of control chemicals at the rhizosphere level [14]. They are involved in several biogeochemical processes including mineralization, soil solubility of inorganic compounds in soil [15] and are known for their ability to promote growth and yield even in the most stressed environments in many parts of the world [16] [17]. The safety of several strains of PGPR for humans [18] [19], the environment and their positive effects on the bioavailability of nutrients including nitrogen, phosphorus in soil, and restoration of soil fertility have been reported in numerous studies [20] [21]. It is in this context that the present study aims to evaluate the effects of five rhizobacteria (PGPR) isolated and identified in central and northern Benin on the growth and yield of maize on ferruginous soils in northern Benin.

\section{Material and Methods}

\subsection{Material}

Strains of PGPR: Five (05) strains of selected on the basis of their ability to 
promote germination parameters in vitro and the growth parameters of maize under the greenhouse [22] are those used. These are: Bacillus panthothenicus, Pseudomonas Cichorii; Pseudomonas Putida; Pseudomonas syringae and Serratia marcescens. They were isolated and characterized from the rhizosphere of maize from different agro-ecological zones of central and northern Benin by [23] and stored at $-20^{\circ} \mathrm{C}$ in Muller Hinton broth with glycerol (10\%) At the laboratory of Biology and molecular typing in microbiology of the University of $\mathrm{Ab}$ omey- Calavi.

Seed of Maize: Maize seeds of the variety 2000 SYNEE-W were used during the study. They are provided by the Northern Agricultural Research Centre (CRA-Nord) of Benin's National Agricultural Research Institute (INRAB). It is an extra-precocious variety with a vegetative cycle of 80 days and a potential yield of $4 \mathrm{t} /$ ha in the plant and a peasant is $2.5 \mathrm{t} / \mathrm{ha}$. It is resistant to breakage, streak, American rust and blight. It is moderately resistant to drought. It tolerates pests [24].

\subsection{Description of the Study Site}

The study was conducted on a leached tropical ferruginous soil at the station of the North Agricultural research Centre located at Ina at an altitude of 358 metres between latitude $9^{\circ} 58^{\prime} \mathrm{N}$ and longitude $2^{\circ} 44^{\prime} \mathrm{E}$ in the municipality of Bembèrèkè, Department of Borgou at north-east of Benin (Figure 1). There is a tropical climate of the Sudanese type characterized by a dry season from October to April and a rainy season from May to September. Rainfall varies between 1100 and $1200 \mathrm{~mm}$ with an evapotranspiration (ETP) of $1600 \mathrm{~mm}$ [25].

\subsection{Experimental Device and Fertilization}

The experimental design was a complete random block of 15 treatments. Each treatment was repeated 3 times on elementary plots of 5 lines of $4 \mathrm{~m}$ with 8 pockets. The distance is $0.80 \mathrm{~m}$ (between the lines) and $0.40 \mathrm{~m}$ (between the pockets). The treatments compared are defined as follows: CTL: Control (no bacteria, no mineral fertilizers); half of the recommended dose of $\mathrm{N}_{13} \mathrm{P}_{17} \mathrm{~K}_{17}$ fertilizers (50\% NPK); recommended dose of $\mathrm{N}_{13} \mathrm{P}_{17} \mathrm{~K}_{17}$ fertilizers (100\% NPK); T1: Bacillus pantothenticus; T2: Pseudomonas cichorii; T3: Pseudomonas putida; T4: Pseudomonas syringae; T5: Serratia marcescens; T6: Serratia marcescen + Pseudomonas Putida; $\mathrm{T} 1+$ half of the recommended dose of $\mathrm{N}_{13} \mathrm{P}_{17} \mathrm{~K}_{17}$ fertilizers $(\mathrm{T} 1+50 \% \mathrm{NPK}) ; \mathrm{T} 2+$ half of the recommended dose of $\mathrm{N}_{13} \mathrm{P}_{17} \mathrm{~K}_{17}$ fertilizers (T2 $+50 \% \mathrm{NPK}) ; \mathrm{T} 3+$ half of the recommended dose of $\mathrm{N}_{13} \mathrm{P}_{17} \mathrm{~K}_{17}$ fertilizers (T3 + $50 \% \mathrm{NPK}$ ); $\mathrm{T} 4+$ half of the recommended dose of $\mathrm{N}_{13} \mathrm{P}_{17} \mathrm{~K}_{17}$ fertilizers (T4 + $50 \% \mathrm{NPK}$ ); $\mathrm{T} 5+$ half of the recommended dose of $\mathrm{N}_{13} \mathrm{P}_{17} \mathrm{~K}_{17}$ fertilizers (T5 + $50 \% \mathrm{NPK}$ ); $\mathrm{T} 6+$ half of the recommended dose of $\mathrm{N}_{13} \mathrm{P}_{17} \mathrm{~K}_{17}$ fertilizers (T6 + $50 \% \mathrm{NPK}$ ). For the fertilization of the experimental plots, $\mathrm{N}_{13} \mathrm{P}_{17} \mathrm{~K}_{17}$ (maize fertilizer) and Urea $(46 \% \mathrm{~N})$ of the recommended doses were applied 15 days after emergence (15 DAE) and $45 \mathrm{DAE}$, respectively, depending on the treatments. 


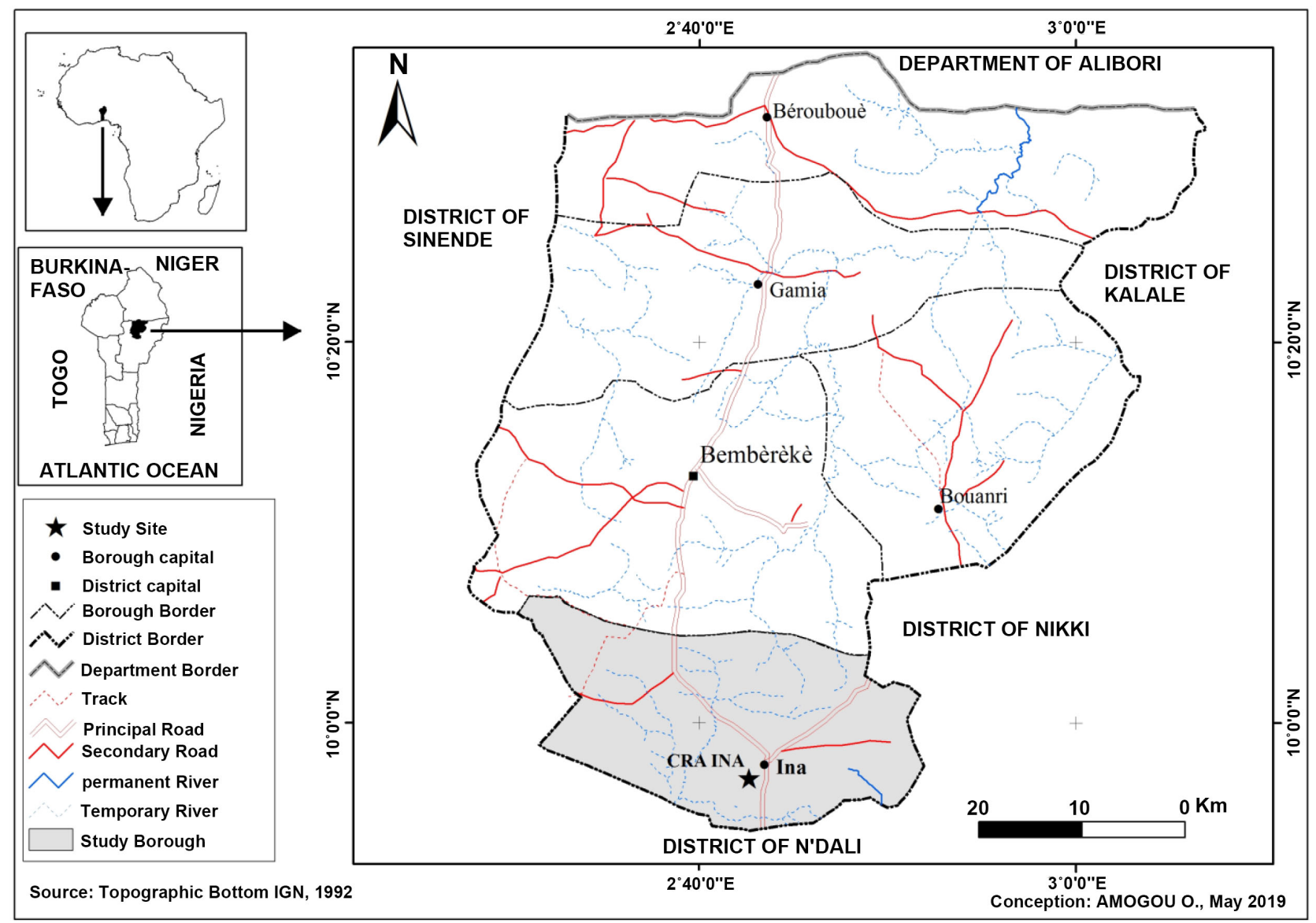

Figure 1. Map of the study area showing the experimental site (AMOGOU O., 2019).

Both urea and NPK fertilizer were buried in the soil at a depth of about 3 to $5 \mathrm{~cm}$ followed by the closure of the hole to prevent losses by leaching and volatilization. Pockets were made near each foot of corn plant.

\subsection{Soil Chemical Analysis of the Experimental Site}

A composite sample $(300 \mathrm{~g})$ of soil collected $(0-20 \mathrm{~cm})$ from the experimental site prior to the installation of the test was analyzed at laboratory of soil Sciences, water and Environment (LSSEE) of the National Institute of Agricultural Research of Benin (INRAB). The analyses consisted of the determination of nitrogen according to the method of [26], phosphorus assimilated by the extraction method of Bray 1 [27], carbon according to the method of [28]. The exchangeable bases (Ca, $\mathrm{Mg}, \mathrm{Na}, \mathrm{K}$ ) [29] as well as the $\mathrm{pH}$ in proportion of 2:1 (Soil: Solution) [30] were also determined.

\subsection{Preparation of the Inoculum of PGPR Strains}

After revivification of Pseudomonas strains on King B medium [30] and those of Bacillus and Serratia on nutrient agar [31] [32], a pure colony of each strain was cultured in nutrient broth (Muller Hinton Broth) medium and incubated at 
$30^{\circ} \mathrm{C}$ for $24 \mathrm{~h}$. The bacterial suspensions obtained were adjusted to approximately $1 \times 10^{8} \mathrm{CFU} / \mathrm{ml}$ (OD 0.45 to $610 \mathrm{~nm}$ ) using the spectrophotometer (BioMATE 3S, Thermo scientific) as described by [33].

\subsection{Sowing, Inoculation of Maize Seeds and Maintenance of Plots}

Two seeds of each treatment was sown at the depth of $5 \mathrm{~cm}$. The seeds were inoculated with $10 \mathrm{ml}$ of bacterial suspension in accordance with the treatments and the hole was immediately closed. Two weeding towers were carried out 12 days after sowing (DAS) and 42 DAS respectively for the maintenance of the various plots. Thinning to one plant per hil was done at 15 DAS.

\subsection{Data Collection}

\subsubsection{Parameters Related to the Growth of Maize Plants}

The height and stem diameter of nine plants maize selected on the three central row of each plot were measured at every 7 days, respectively, using a ruler tape and the caliper from the thinning of the plants until the end of the trial. In addition, the leaf area of plants was estimated at 63th DAS by the product of length and width of leaves affected by coefficient 0.75 [34].

\subsubsection{Parameters Related to Yield}

Nine plant maize per field hole were harvest 70 DAS and data was recorded for fresh biomass (by weighing using a precision scale), shoot and root dry weight after drying in an oven at $100^{\circ} \mathrm{C}$ for three days to constant weight. Maize cobs were shelled and weighed in accordance with the treatment. The moisture percentage of the grain was evaluated using a moisture meter (LDS-1F). On each elemental parcel, the average grain yield was calculated using the formula below used by [35].

$$
R=\frac{P \times 10.000}{S I \times 1.000} \times \frac{14 \%}{H}
$$

whereas $\mathrm{R}$ is the average yield of maize, expressed in $\mathrm{t} / \mathrm{ha} ; P$ is the fresh weight of maize per basic calculation area, expressed in $\mathrm{kg}$; $S I$ is the surface interpretable in $\left(\mathrm{m}^{2}\right) ; H$ is the moisture content of the grains, expressed \%; 10,000 represents the conversion of ha in $\mathrm{m}^{2} ; 1000$ represents the conversion of tone $(\mathrm{t})$ in $\mathrm{kg}$.

\subsection{Determination of the Nutritional Status of Maize Plants}

Samples of two whole maize plants removed from each elemental parcel were formed. Dry matter obtained after drying followed by grinding was digested according to the wolf method. The assessment of the nutritional status of the seedlings consisted to the determination of the phosphorus (P) content by flame emission and by Colorimetry [36], nitrogen $(\mathrm{N})$ using the Kjeldahl method as described by [37] and potassium by the atomic absorption Spectrophotometer [38]. In terms of calcium ( $\mathrm{Ca})$ and magnesium $(\mathrm{Mg})$, they were evaluated using the [39] method. 


\subsection{Statistical Analysis}

The data were analyzed with $\mathrm{R}$ 3.4.4 software and required the use of packages such as agricultural and graphics. Data have been previously transformed into a logarithm and square root and then subjected to an analysis of variance with the exception of data on height, fresh aerial biomass, grain yield and calcium (Ca) content for which the Kruskal-Wallis $(\mathrm{p}<0.05)$ test has been used. The choice of this non-parametric test was motivated by the fact that the averages of these variables are not normally distributed. The differences among various treatment means were achieved using the student-Newman-Keuls test at the 5\% ( $\mathrm{p} \leq 0.05)$ probability level. Finally, an ascending hierarchical classification (CHA) was performed on the average of the different parameters by treatment to group them into homogeneous classes. The graph Pad software Prism version 7.00 has been used to plot graphs.

\section{Results}

\subsection{Soil Chemical Characteristics of the Experimental Site}

The analysis in Table 1 reveals that the organic matter $\left(9.5 \mathrm{~g} \cdot \mathrm{kg}^{-1}\right)$, nitrogen $(0.8$ $\left.\mathrm{g} \cdot \mathrm{kg}^{-1}\right)$ and the content $\left(3 \mathrm{mg} \cdot \mathrm{kg}^{-1}\right)$ of phosphorus are low in the soil of the experimentation site. The sum of the bases $(1.82 \mathrm{Cmol} \cdot \mathrm{kg})$ and cation exchange capacity $(4.64 \mathrm{Cmol} \cdot \mathrm{kg})$ are also low. $\mathrm{pH}$ values $(\mathrm{pH}$-water $=5.54$ and $\mathrm{pH}-\mathrm{KCl}=$ 5.03 ) showed that the study soil was moderately acidic. These chemical properties reflect a limited fertility of the study soil because of its low stored nutrient reserves.

\subsection{Effects of PGPR on the Growth Parameters of Maize Plants}

The effect of inoculation of PGPR on the height and stem diameter of maize plants was very highly significant at $\mathrm{p}<0.001$ for stem diameter and highly significant at $\mathrm{p}<0.05$ for height (Table 2). Seedlings inoculated with $S$. marcescens $+50 \%$ NPK exhibited the highest heights with an improvement of more than $41.09 \%$ compared with un-inoculated plants and $3.14 \%$ compared to plants receiving $100 \%$ NPK. The lowest heights were recorded at the level of the control plants. As for the stem diameter, the highest mean values were $2.14 \mathrm{~cm}, 2.06 \mathrm{~cm}$ and $2.01 \mathrm{~cm}$, respectively, with $100 \% \mathrm{NPK}, S$. marcescens $+50 \mathrm{NPK}$, and $P . p u-$ tida $+50 \%$ NPK, which induced improvement in the same order of $49.65 \%$, $43.35 \%$ and $39.86 \%$ per comparison to the control plants. On the other hand, no positive effects were observed with $B$. pantothenticus treatment and the $S$. marcescens $+P$. putida combination for this parameter. For the leaf area of the seedlings, the inoculation treatment with the PGPR Rhizobacteria showed a very highly significant difference with the un-inoculated controls $(\mathrm{p}<0.001)$. It is observed from the analysis of the results (Table 2 ) that the largest leaf area values were obtained with the plants treated with $P$. putida + 50\% NPK (466.38 $\left.\mathrm{cm}^{2}\right)$ followed by $S$. marcescens $+50 \%$ NPK $\left(452.08 \mathrm{~cm}^{2}\right)$ with a percentage improvement rate of $32.08 \%$ and $28.04 \%$ compared to control plants. 
Table 1. Soil chemical characteristics of the experimental site.

\begin{tabular}{|c|c|c|c|c|c|c|c|c|c|c|c|c|c|}
\hline \multirow{3}{*}{ Soil } & \multicolumn{4}{|c|}{$\mathrm{pH}$} & \multicolumn{9}{|c|}{ B.E $(\mathrm{meq} / 100 \mathrm{~g})$} \\
\hline & & & $\mathrm{C}$ & $\mathbf{N}$ & $\mathrm{C} / \mathrm{N}$ & MO & $P$.ass & $\mathrm{Ca}$ & $\mathrm{Mg}$ & $\mathrm{K}$ & $\mathrm{Na}$ & SB & CEC \\
\hline & Eau & $\mathrm{Kcl}$ & $\%$ & $\%$ & $\%$ & $\%$ & ppm\% & & & & & $\%$ & meq/100 g \\
\hline & 5.54 & 5.03 & 0.55 & 0.08 & 6.88 & 0.95 & 3.00 & 0.94 & 0.54 & 0.15 & 0.17 & 1.82 & 4.64 \\
\hline
\end{tabular}

Table 2. Effects of PGPR on maize plant growth parameters.

\begin{tabular}{cccc}
\hline Treatments & Height $(\mathrm{cm})$ & Stem Diameter $(\mathrm{cm})$ & Leaf Area $\left(\mathrm{cm}^{2}\right)$ \\
\hline CTL & $\mathrm{m} \pm \mathrm{sd}$ & $\mathrm{m} \pm \mathrm{sd}$ & $\mathrm{m} \pm \mathrm{sd}$ \\
\hline 50\% NPK & $116.94 \pm 24.54 \mathrm{a}$ & $1.43 \pm 0.10 \mathrm{e}$ & $353.10 \pm 21.72 \mathrm{c}$ \\
100\% NPK & $138.16 \pm 12.01 \mathrm{a}$ & $1.83 \pm 0.07 \mathrm{abcd}$ & $361.13 \pm 30.66 \mathrm{c}$ \\
T1 & $161.33 \pm 15.88 \mathrm{a}$ & $2.13 \pm 0.15 \mathrm{a}$ & $413.79 \pm 9.37 \mathrm{~b}$ \\
T2 & $135.83 \pm 30.42 \mathrm{a}$ & $1.4 \pm 0.14 \mathrm{e}$ & $372.82 \pm 27.22 \mathrm{bc}$ \\
T3 & $131.88 \pm 15.15 \mathrm{a}$ & $1.74 \pm 0.01 \mathrm{abcde}$ & $391.92 \pm 14.88 \mathrm{bc}$ \\
T4 & $136.22 \pm 30.34 \mathrm{a}$ & $1.7 \pm 0.30 \mathrm{bcde}$ & $361.98 \pm 24.4 \mathrm{c}$ \\
T5 & $132.61 \pm 19.20 \mathrm{a}$ & $1.46 \pm 0.14 \mathrm{de}$ & $394.18 \pm 6.18 \mathrm{bc}$ \\
T6 & $135.94 \pm 11.11 \mathrm{a}$ & $1.56 \pm 0.06 \mathrm{cde}$ & $374.84 \pm 13.72 \mathrm{bc}$ \\
T1 + 50\% NPK & $132.22 \pm 8.21 \mathrm{a}$ & $1.41 \pm 0.06 \mathrm{e}$ & $363.46 \pm 4.36 \mathrm{c}$ \\
T2 + 50\% NPK & $149.83 \pm 23.50 \mathrm{a}$ & $1.83 \pm 0.10 \mathrm{abcd}$ & $443.13 \pm 1.85 \mathrm{a}$ \\
T3 + 50\% NPK & $158.16 \pm 7.22 \mathrm{a}$ & $1.89 \pm 0.07 \mathrm{abc}$ & $398.83 \pm 8.04 \mathrm{bc}$ \\
T4 + 50\% NPK & $158.72 \pm 9.84 \mathrm{a}$ & $1.77 \pm 0.29 \mathrm{abcde}$ & $364.78 \pm 19.42 \mathrm{c}$ \\
T5 + 50\% NPK & $165 \pm 7.62 \mathrm{a}$ & $2.05 \pm 0.04 \mathrm{ab}$ & $452.12 \pm 10.10 \mathrm{a}$ \\
T6 + 50\% NPK & $154.61 \pm 6.61 \mathrm{a}$ & $1.91 \pm 0.113 \mathrm{abc}$ & $453.92 \pm 13.50 \mathrm{a}$ \\
$\boldsymbol{p}$-value & $\mathbf{0 . 0 4 7 4 3}$ & $<0.001$ & $<0.001$ \\
Signification & $* *$ & $* * *$ & $* * *$ \\
\hline
\end{tabular}

Value: mean \pm standard deviation, NS $=p>0.05$ : not significant. CTL: control (no bacteria, no mineral fertilizers); T1: Bacillus pantothenticus, T2: Pseudomonas cichorii; T3: Pseudomonas putida; T4: Pseudomonas syringae, T5: Serratia marcescens; T6: Serratia marcescens + Pseudomonas putida.

\subsection{Classification of Treatments on the Basis of Growth Parameters}

In order to consolidate the treatments into sufficiently homogeneous groups, an ascending hierarchical classification was carried out (Figure 2). The dendrogram below shows three as the optimal number of groups to be retained for classification of treatments. Group 1 (G1) whose heights, leaf surfaces and stem diameters were significantly improved, consisting of four (04) treatments (T1 + $50 \% \mathrm{NPK}, \mathrm{T} 3+50 \% \mathrm{NPK}, \mathrm{T} 5+50 \% \mathrm{NPK}$, and T6 + 50\% NPK). Group 2 (G2) has seven (07) treatments (CTL, T4 + 50\% NPK, T5, T1, T6, 50\% NPK and T3) and all plants fertilized with $100 \%$ NPK as well as those inoculated with other rhizobacteria are classified in Group 3 (G3). 


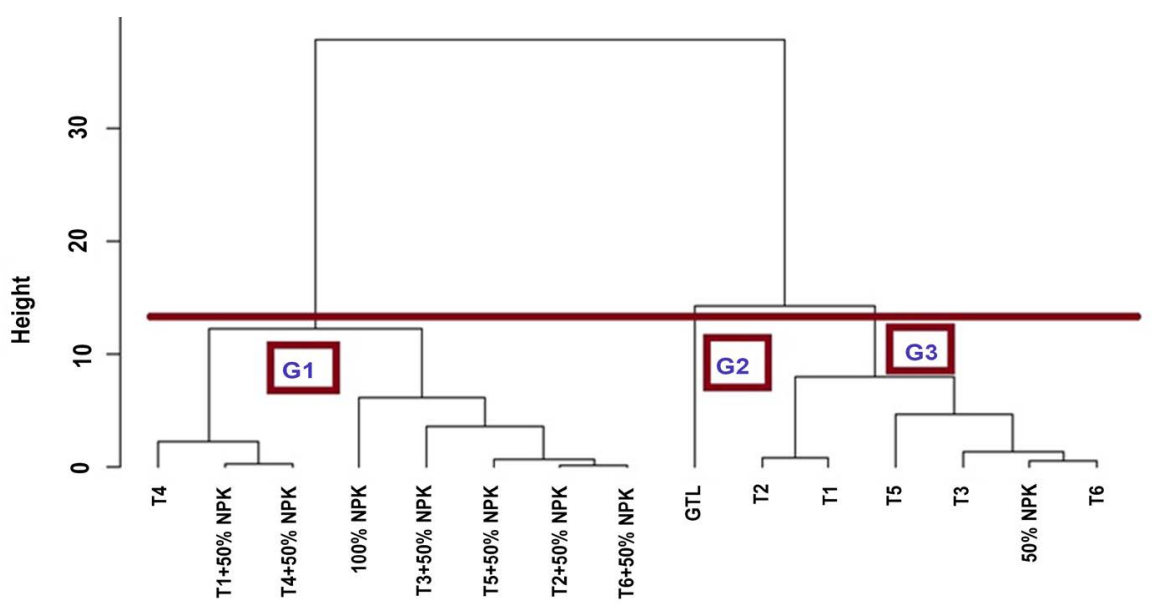

Figure 2. Dendrogram of groups Hierachiques. CTL: controle (no bacteria, no mineral fertilizer); T1: Bacillus pantothenticus, T2: Pseudomonas cichorii; T3: Pseudomonas putida; T4: Pseudomonas syringae; T5: Serratia marcescens; T6: Serratia marcescens+ Pseudomonas putida.

\subsection{Effects of PGPR on the Yield Parameters of Maize Plants}

\subsubsection{Fresh Biomass of Maize Plants}

The fresh weight of the aerial biomass (Figure 3(a)) and underground biomass (Figure $3(\mathrm{~b})$ ) of maize plants was significantly improved $(\mathrm{p}<0.001)$ for the majority of seedlings inoculated against controls. Among the inocula tested, the best results were observed in $S$. marcescens $+50 \%$ NPK with a percentage improvement of $144.28 \%$ for aboveground biomass and $117.5 \%$ for underground biomass followed by $P$. putida $+50 \%$ NPK with an improvement percentage of $71.45 \%$ for aboveground biomass and $66.66 \%$ for underground biomass. Fertilization of maize plants with $100 \%$ NPK resulted in the recording of $1433.33 \mathrm{~g}$ of aboveground biomass and $216.67 \mathrm{~g}$ of underground biomass. These results show that there is no difference between the effects induced by $S$. marcescens $+50 \%$ NPK and the $100 \%$ NPK treatment on the fresh biomass yield of maize plants. On the other hand, B. pantothenticus and P. syringae induced a decrease in aboveground fresh biomass compared with controls.

\subsubsection{Dry Biomass and Grain Yield Produced by Maize Plants}

The influence of PGPR on the yield parameters (dry biomass and grain yield) produced by maize plants is illustrated in Table 3. Analysis of the variance applied to the averages of dry biomass and grain yield of maize plants showed a very highly significant difference $(\mathrm{p}<0.001)$ between the different treatments. The most important production of dry aerial biomass was recorded with the treatments $S$. marcescens $+50 \%$ NPK followed by $P$. putida $+50 \%$ NPK with the respective improvement percentages of $213.34 \%$ and $131.79 \%$ compared to the un-inoculated plants. All the isolated tested increased underground biomass, except for the combination of $P$. putida and $S$. marcescens. The most effective bacterial treatment ( $S$. marcescens $+50 \% \mathrm{NPK}$ ) induced an increase of $5.41 \%$ and $140.38 \%$, respectively, compared with $100 \%$ NPK treatment and un-inoculated 


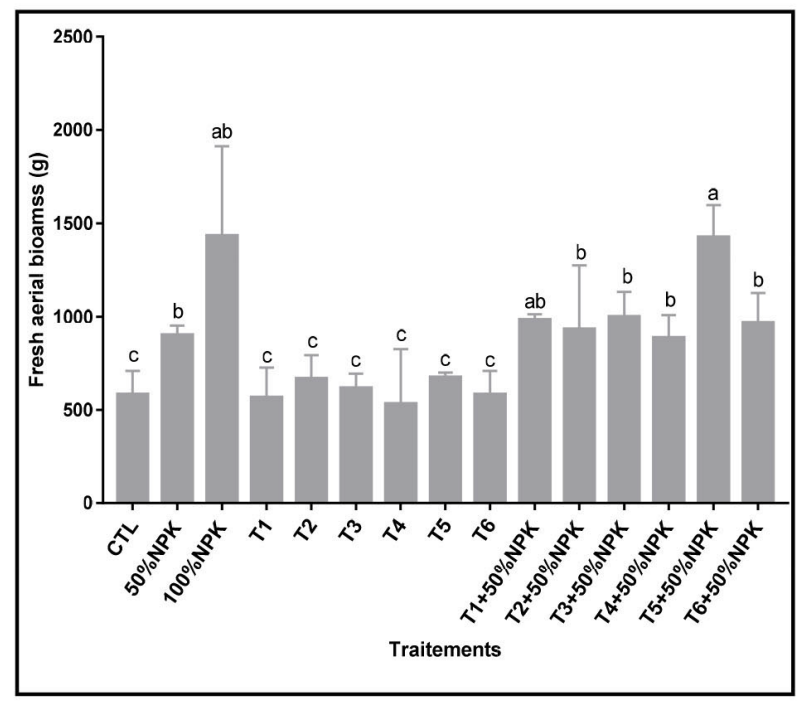

(a)

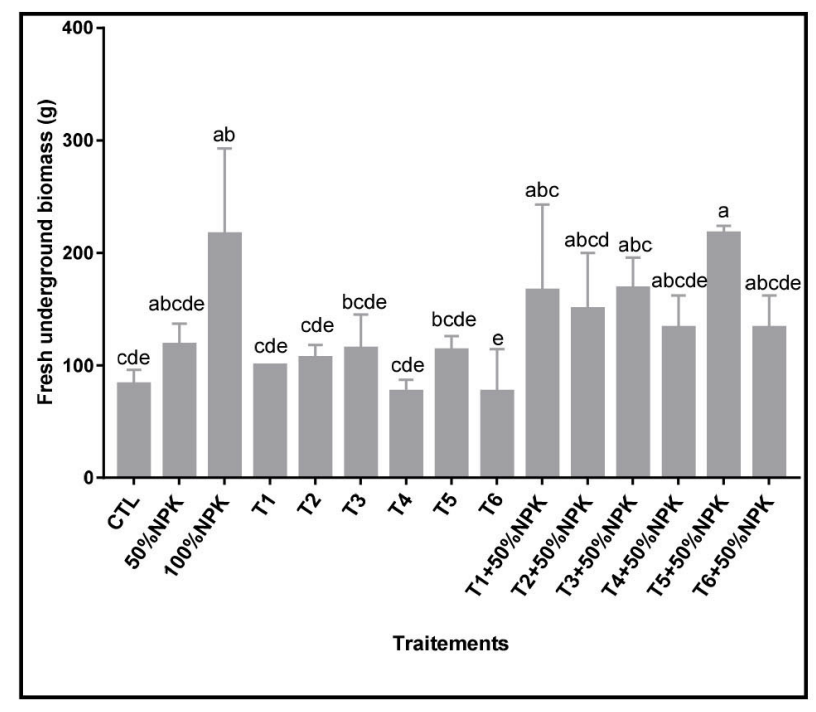

(b)

Figure 3. Effect of PGPR on fresh aerial biomass of maize plants (a) and fresh underground biomass of maize plants (b). CTL: control (no bacteria, no mineral fertilizer); T1: Bacillus pantothenticus; T2: Pseudomonas cichorii; T3: Pseudomonas putida; T4: Pseudomonas syringae; T5: Serratia marcescens; T6: Serratia marcescens + Pseudomonas putida.

plants. It was followed by $P$. putida $+50 \%$ NPK which obtained the similar yield $(113.28 \mathrm{~g})$ as that recorded at the level of the plants fertilized with $100 \%$ NPK with an improvement rate of $128.84 \%$ compared to the control plants. At the reading of Table 3 , the efficacy of different isolates for grain yield was variable. All the inoculated treatments showed grain yield, significantly higher than control. Maximum grain yield $(2.356 \pm 0.21 \mathrm{ha} / \mathrm{t})$, obtained with $S$. marcescens + $50 \%$ NPK was $39.05 \%$ greater than in the non-inoculated control. It followed by $100 \%$ NPK (full dose of NPK) and P. putida $+50 \%$ NPK which induced $35.5 \%$ and $34.91 \%$ compared to control, respectively.

\subsubsection{Classification of Treatments Based on Yield Parameters}

Analysis of the dendrogram (Figure 4) shows that the 15 treatments were divided into three (3) groups. The first group (G1) includes treatments such as T2, $\mathrm{T} 3$, and T5 applied without the addition of chemical fertilizers, which induced improvement in performance parameters compared to control. The others (T4, T1, CTL, and T6) are characterized by their negative effect on grain yield compared to controls. Group 2 (G2) consists of two (02) treatments 100\% NPK and T5 $+50 \%$ NPK, which induced the highest yields of biomass and in maize seeds. Group 3 (G3) is subdivided into two subgroups. Group 3 G3 (1) is composed of plants fertilized with 50\% NPK and those inoculated with T4 + 50\% NPK. The Group 3 G3 (2) was in turn left in two subgroups, one of which consists of the plants inoculated with T3 $+50 \%$ NPK characterized by yields of dry biomass and high seed in comparison with controls and the second in which the plants are found on influence of T $2+50 \%$ NPK, T $6+50 \%$ NPK and T $1+50 \%$ NPK. 
Table 3. Effect of PGPR on dry biomass and grain yield.

\begin{tabular}{cccc}
\hline \multirow{2}{*}{ Treatments } & Dry Aerial Biomass & Dry Underground Biomass & Grain yield \\
\cline { 2 - 4 } & $\mathrm{m} \pm \mathrm{sd}$ & $\mathrm{m} \pm \mathrm{sd}$ & $\mathrm{m} \pm \mathrm{sd}$ \\
\hline CTL & $306.13 \pm 80.67 \mathrm{~d}$ & $49.50 \pm 2.23 \mathrm{bc}$ & $1.696 \pm 0.156 \mathrm{gh}$ \\
50\% NPK & $504.14 \pm 34.17 \mathrm{bcd}$ & $73.80 \pm 15.15 \mathrm{abc}$ & $1.811 \pm 0.024 \mathrm{fgh}$ \\
100 NPK & $856.5 \pm 173.74 \mathrm{ab}$ & $112.88 \pm 44.90 \mathrm{a}$ & $2.299 \pm 0.200 \mathrm{ab}$ \\
T1 & $305.82 \pm 92.31 \mathrm{~d}$ & $61.39 \pm 3.88 \mathrm{abc}$ & $1.574 \pm 0.157 \mathrm{~h}$ \\
T2 & $342.18 \pm 67.93 \mathrm{~d}$ & $64.60 \pm 10.09 \mathrm{abc}$ & $1.929 \pm 0.088 \mathrm{defg}$ \\
T3 & $369.67 \pm 156.64 \mathrm{~cd}$ & $63.53 \pm 20.86 \mathrm{abc}$ & $1.967 \pm 0.144 \mathrm{cdef}$ \\
T4 & $310.19 \pm 156.64 \mathrm{~d}$ & $66.44 \pm 18.43 \mathrm{abc}$ & $1.592 \pm 0.139 \mathrm{~h}$ \\
T5 & $395.99 \pm 81.49 \mathrm{~cd}$ & $72.33 \pm 17.69 \mathrm{abc}$ & $1.996 \pm 0.470 \mathrm{def}$ \\
T6 & $320.17 \pm 97.31 \mathrm{~d}$ & $45.83 \pm 7.29 \mathrm{c}$ & $1.641 \pm 0.125 \mathrm{~h}$ \\
T1 + 50\% NPK & $595.85 \pm 89.23 \mathrm{abcd}$ & $99.94 \pm 33.63 \mathrm{ab}$ & $1.880 \pm 0.055 \mathrm{efg}$ \\
T2 + 50\% NPK & $603.70 \pm 221.99 \mathrm{abcd}$ & $101.30 \pm 31.62 \mathrm{ab}$ & $2.132 \pm 0.120 \mathrm{abcd}$ \\
T3 + 50\% NPK & $709.50 \pm 124.40 \mathrm{abc}$ & $113.28 \pm 16.13 \mathrm{a}$ & $2.284 \pm 0.425 \mathrm{abc}$ \\
T4 + 50\% NPK & $559.18 \pm 99.90 \mathrm{abcd}$ & $93.88 \pm 33.11 \mathrm{abc}$ & $1.936 \pm 0.065 \mathrm{efg}$ \\
T5 + 50\% NPK & $959.24 \pm 259.78 \mathrm{a}$ & $118.99 \pm 25.51 \mathrm{a}$ & $2.356 \pm 0.210 \mathrm{a}$ \\
T6 + 50\% NPK & $617.60 \pm 86.92 \mathrm{abcd}$ & $87.35 \pm 17.62 \mathrm{abc}$ & $1.970 \pm 0.063 \mathrm{bcde}$ \\
P-value & $<0.001$ & $<0.001$ & 0.00183 \\
Signification & $* * *$ & $* * *$ & $* *$ \\
\hline
\end{tabular}

Value: mean \pm standard deviation, $N S=p>0.05$ : not significant. CTL: control (no bacteria, no mineralfertilizers); T1: Bacillus pantothenticus, T2: Pseudomonas cichorii; T3: Pseudomonas putida; T4: Pseudomonas syringae, T5: Serratia marcescens; T6: Serratia marcescens + Pseudomonas putida.

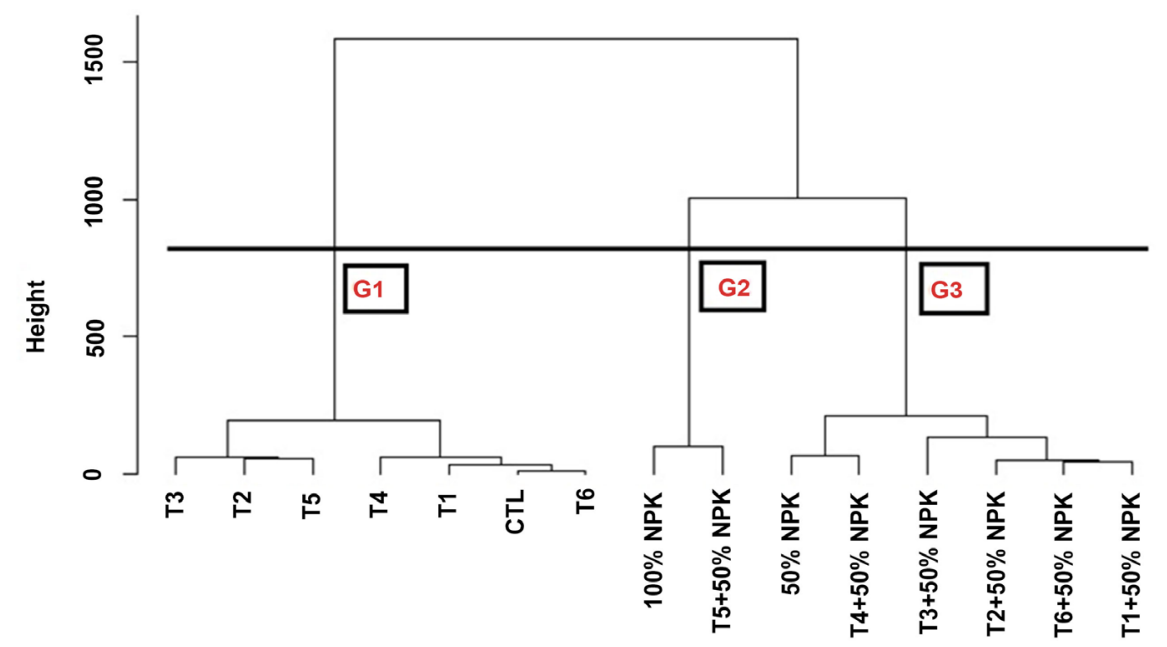

Figure 4. Dendrogram showing hierarchical classification of treatments. CTL: control (no bacteria, no mineral fertilizer); T1: Bacillus pantothenticus, T2: Pseudomonas cichorii; T3: Pseudomonas putida; T4: Pseudomonas syringae; T5: Serratia marcescens, T6: Serratia marcescens + Pseudomonas putida. 


\subsection{Effect of PGPR on the Nutritional Status of Maize Plants}

The effect of PGPR on nutrient assimilation was highly variable from one strain to another (Table 4$)$. Indeed, the best content $(1.239 \% \pm 0.09 \%)$ of nitrogen $(\mathrm{N})$ absorbed by the seedlings was recorded with the inoculation of $S$. marcescens, an increase of $3.76 \%$ over the control plants. This content is followed by that $(1.232 \% \pm 0.05 \%)$ obtained at the level of the plants fertilized with the full dose of mineral fertilizers (100\% NPK). In addition, the effect of $P$. putida and $P$. cichorii $+50 \%$ NPK resulted in a $25 \%$ improvement rate for phosphorus (P) uptake. The best absorption of calcium $(0.180 \% \pm 0.05 \%)$ was recorded at the level of plants that received $P$. cichorii $+50 \%$ NPK. The latter induced an improvement of $38.46 \%$ in comparison with the control plants. Calcium uptake was also stimulated by inoculation of $S$. marcescens and $P$. putida, which induced a similar increase of $20.45 \%$ in comparison with control plants. For potassium (K) and magnesium $(\mathrm{Mg})$, their elevated levels were obtained with the inoculation of $P$. cichorii, an improvement of $12.35 \%$ and $10.85 \%$ in comparison with control plants. Analysis of the variance applied to mean N, P, K, Ca, and Mg concentrations indicated that there was no significant difference $(p>0.005)$ between the different treatments (Table 4).

\section{Discussion}

The use of PGPR is increasingly gaining its place as a widespread practice in agriculture to replace the excessive and uncontrollable use of chemical fertilizers [40]. The present investigation on ferruginous soil in northern Benin revealed the significant effect of inoculation of rhizobacteria on maize growth and yield and therefore a reduction in the dose of NPK fertilizer recommended by the services of extension. The low soil fertility status of the study environment (low nitrogen, phosphorus, organic matter) corroborates the results of the soil analysis (Table 1) and is also consistent with the finding made by [41]. This author has reported that organic matter has a major influence on the physical and chemical properties of soils. The study soil is of a weakly acidic nature ( $\mathrm{pH}$-water $=5.54$ and $\mathrm{pH}-\mathrm{KCl}=5.03$ ) as indicated [42] which asserted that soils characterized by $\mathrm{pH}$ values ranging from 5.1 to 5.5 are considered weakly acidic. Igué et al. [43] reported that the $\mathrm{pH}$ of such soils is favorable for good mineralization of mineral elements. It is also one of the main soil indicators that influences biological processes such as atmospheric nitrogen fixation and degradation of organic matter, which can limit the growth and yield of agricultural crops.

The different results of the test for growth parameters (Table 2) show that the plants that received $S$. marcescens $+50 \%$ NPK followed by $P$. putida $+50 \%$ NPK induced a significant increase in height, respectively, of $41.09 \%$ and $35.24 \%$ compared to control plants. The performance recorded for this parameter with S. marcescens $+50 \%$ NPK was $3.14 \%$ higher over $100 \%$ NPK treatment. These results are similar to those obtained in India by [44]. During two successive years of experimentation, the authors of this study reported significant improvements of 
Table 4. Effects of PGPR on the nutritional status of maize plants.

\begin{tabular}{|c|c|c|c|c|c|}
\hline & $\% \mathrm{~N}$ & $\% \mathrm{P}$ & $\% \mathrm{~K}$ & $\% \mathrm{Ca}$ & $\% \mathrm{Mg}$ \\
\hline & $\mathrm{m} \pm \mathrm{sd}$ & $\mathrm{m} \pm \mathrm{sd}$ & $\mathrm{m} \pm \mathrm{sd}$ & $\mathrm{m} \pm \mathrm{sd}$ & $\mathrm{m} \pm \mathrm{sd}$ \\
\hline CTL & $1.194 \pm 0.16 a$ & $0.088 \pm 0.01 \mathrm{a}$ & $0.896 \pm 0.04 \mathrm{a}$ & $0.132 \pm 0.00 \mathrm{a}$ & $0.129 \pm 0.00 \mathrm{a}$ \\
\hline $50 \%$ NPK & $1.150 \pm 0.19 a$ & $0.070 \pm 0.03 a$ & $0.812 \pm 0.11 \mathrm{a}$ & $0.143 \pm 0.00 \mathrm{a}$ & $0.115 \pm 0.00 \mathrm{a}$ \\
\hline $100 \%$ NPK & $1.232 \pm 0.05 a$ & $0.097 \pm 0.02 \mathrm{a}$ & $0.783 \pm 0.09 \mathrm{a}$ & $0.152 \pm 0.01 \mathrm{a}$ & $0.116 \pm 0.01 \mathrm{a}$ \\
\hline T1 & $1.052 \pm 0.11 \mathrm{a}$ & $0.083 \pm 0.00 \mathrm{a}$ & $0.763 \pm 0.08 \mathrm{a}$ & $0.146 \pm 00$ & $0.138 \pm 0.01 \mathrm{a}$ \\
\hline $\mathrm{T} 2$ & $1.224 \pm 0.10 \mathrm{a}$ & $0.091 \pm 0.02 \mathrm{a}$ & $1.005 \pm 0.25 \mathrm{a}$ & $0,147 \pm 0.01 \mathrm{a}$ & $0.144 \pm 0.01 \mathrm{a}$ \\
\hline T3 & $1.008 \pm 0.16 \mathrm{a}$ & $0.101 \pm 0.00 \mathrm{a}$ & $0.856 \pm 0.13 \mathrm{a}$ & $0,152 \pm 0.01 \mathrm{a}$ & $0.132 \pm 0.01 \mathrm{a}$ \\
\hline T4 & $1.149 \pm 0.10 \mathrm{a}$ & $0.098 \pm 0.02 \mathrm{a}$ & $0.763 \pm 0.13 \mathrm{a}$ & $0,149 \pm 0.01 \mathrm{a}$ & $0.129 \pm 0.01 \mathrm{a}$ \\
\hline T5 & $1.239 \pm 0.09 a$ & $0.076 \pm 0.01 \mathrm{a}$ & $0.679 \pm 0.01 \mathrm{a}$ & $0.159 \pm 0.03 a$ & $0.119 \pm 0.04 \mathrm{a}$ \\
\hline T6 & $1.067 \pm 0.07 \mathrm{a}$ & $0.075 \pm 0.00 \mathrm{a}$ & $0.749 \pm 0.10 \mathrm{a}$ & $0.143 \pm 0.00 \mathrm{a}$ & $0.114 \pm 0.01 \mathrm{a}$ \\
\hline $\mathrm{T} 1+50 \% \mathrm{NPK}$ & $0.941 \pm 0.11 \mathrm{a}$ & $0.071 \pm 0.01 \mathrm{a}$ & $0.801 \pm 0.11 \mathrm{a}$ & $0.144 \pm 0.00 \mathrm{a}$ & $0.109 \pm 0.01 \mathrm{a}$ \\
\hline $\mathrm{T} 2+50 \% \mathrm{NPK}$ & $1.083 \pm 0.13 a$ & $0.109 \pm 0.02 \mathrm{a}$ & $0.816 \pm 0.15 \mathrm{a}$ & $0.180 \pm 0.05 a$ & $0.115 \pm 0.00 \mathrm{a}$ \\
\hline $\mathrm{T} 3+50 \% \mathrm{NPK}$ & $0.948 \pm 0.01 \mathrm{a}$ & $0.080 \pm 0.00 \mathrm{a}$ & $0.929 \pm 0.15 \mathrm{a}$ & $0.159 \pm 0.03 \mathrm{a}$ & $0.127 \pm 0.01 \mathrm{a}$ \\
\hline $\mathrm{T} 4+50 \% \mathrm{NPK}$ & $1.008 \pm 0.16 \mathrm{a}$ & $0.089 \pm 0.01 \mathrm{a}$ & $0.806 \pm 0.06 \mathrm{a}$ & $0.146 \pm 0.00 \mathrm{a}$ & $0.124 \pm 0.01 \mathrm{a}$ \\
\hline $\mathrm{T} 5+50 \% \mathrm{NPK}$ & $1.090 \pm 0.06 \mathrm{a}$ & $0.097 \pm 0.02 \mathrm{a}$ & $0.840 \pm 0.08 \mathrm{a}$ & $0.131 \pm 0.01 \mathrm{a}$ & $0.106 \pm 0.00 \mathrm{a}$ \\
\hline T6 + 50\% NPK & $1.037 \pm 0.16 \mathrm{a}$ & $0.066 \pm 0.01 \mathrm{a}$ & $0.681 \pm 0.01 \mathrm{a}$ & $0.162 \pm 0.03 a$ & $0.135 \pm 0.03 \mathrm{a}$ \\
\hline$p$-value & 0.058 & 0.226 & 0.118 & 0.608 & 0.457 \\
\hline Signification & NS & NS & NS & NS & NS \\
\hline
\end{tabular}

Value: mean \pm standard deviation, NS $=\mathrm{p}>0.05$ : not significant. CTL: control (no bacteria, no mineral fertilizers); T1: Bacillus pantothenticus; T2: Pseudomonas cichorii; T3: Pseudomonas putida; T4: Pseudomonas syringae, T5: Serratia marcescens; T6: Serratia marcescens + Pseudomonas putida.

$20.83 \%$ and $14.28 \%$ compared to controls respectively of the height of wheat plants and that of maize with inoculation of Pseudomonas plecoglossicida (PSB-5) in the presence of rock phosphate as fertilizer. Other scientists also observed the increase in plant height by inoculation with Serratia marcescens on tea plant [45] and with Azospirilum on maize plant [46]. The effect of bio-fertilization of $S$. marcescens and $P$. putida and their combination in the presence of a half-dose of recommended mineral fertilizers was also demonstrated on the leaf area of the plants. Inoculation induced a highly significant increase in leaf area in the range of $28.55 \%$ to $32.08 \%$ compared with un-inoculated plants. Ahemad and Kiber [47] stated that mobilization of mineral nutrients like $\mathrm{P}$ and $\mathrm{Fe}$ in soil by rhizobacteria could be the main mechanism for increased growth and development of plants which makes these nutrients in more readily plant available forms. In comparison with control plants, the stem diameter of plants treated with $S$. marcescens $+50 \%$ NPK and P. putida $+50 \%$ NPK increased by $43.35 \%$ and $39.86 \%$, respectively, after 70 days of cultivation. Such results were recently recorded in the work conducted by [48] with the inoculation of Serratia sp. on maize seeds grown on soil infested with Fusarium 
oxysporum and fertilized with $\mathrm{N}_{180} \mathrm{P}_{140} \mathrm{~K}_{90}$ and then in Morocco with the inoculation of Serratia proteamaculans (2025-1) on tomato [49]. Duponnois et al. [50] indicated that the more robust the inoculated seedlings are than the un-inoculated plants, the more likely they are to survive by demonstrating a high capacity to withstand environmental conditions. These results obtained in our study are of great importance because they promote better resistance of maize plants and therefore an improvement in maize productivity in northern Benin in a context where anarchic exploitation of forests induces an acceleration of climate change [51]. On crop productivity (Figure 3), the study revealed a significant effect $(\mathrm{P}<0.01)$ of bacterial inoculation on the fresh biomass yields of maize plants in the presence or in absence of NPK. For the fresh biomass of plants, $S$. marcescens $+50 \%$ NPK induced an increase of $144.28 \%$ in the fresh weight of aboveground biomass and $213.34 \%$ of the fresh weight of roots compared with controls. It is followed by P. putida $+50 \%$ NPK. The latter induced an improvement of $131.79 \%$ of the underground biomass and $71.45 \%$ of the fresh weight of aboveground biomass compared with the control plants. The same trends were observed in the dry matter developed by plants (Table 3) where the efficacy of $S$. marscens $+50 \%$ NPK resulted in a rate of increase of $11.90 \%$ and $5.41 \%$, respectively, of dry aerial biomass and underground biomass dry compared to plants that received 100\% NPK. Similarly, Isfahani and Besharati [52] have reported that Pseudomonas sp. + 50\% NPK (B1 P50) significantly stimulated the dry weight of cucumber roots compared to controls, while the lowest dry weights were recorded at the level of maize plants that received the full dose of $100 \%$ NPK (P100B0) mineral fertilizers. Our results were also consistent with the findings of [53] who observed that inoculation of seeds with Pseudomonas DSMZ 13134 resulted in an improvement in the biomass of maize plants grown on phosphorus deficient acid soil. Data presented in Table 3 also showed that inoculation of PGPR had a significant impact $(\mathrm{P}<0.01)$ on grain yield. Taking into account the results of the classification of all the treatments shown in Figure 4 , it is apparent that in the absence of mineral fertilizers, inoculation of $P$. putida, $S$. marcescens, and $P$. cichorii stimulates the improvement of maize grain yield, a corresponding increase of $17.68 \%, 15.97 \%$ and $13.73 \%$ in comparison with the witness. It is also noted that the addition of a half-dose of NPK increases the effect of these strains on yield. Indeed, the best yields of grains obtained were recorded with the treatments $S$. marcescens $+50 \%$ NPK followed by $P$. putida $+50 \%$ NPK which gave the respective rates of increase of $39.05 \%$ and $34.91 \%$ compared to the un-inoculated plants. These rates reach the $37 \%$ obtained by [54] with inoculation of P. putida 108 on wheat. Our results were also in agreement with the previous study where the yields of rice and sugar beet had been enhanced by inoculation with PGPR alone or in combination with low-dose mineral fertilizers [55] [56]. In Iran, Biari et al. [57] justified the performance of PGPR on maize growth and grain yield by better absorption of $\mathrm{N}, \mathrm{P}$, $\mathrm{K}, \mathrm{Fe}, \mathrm{Zn}, \mathrm{Mn}$, and $\mathrm{Cu}$ nutrients. In our trials, data on the effect of inoculation of PGPR on nutrient absorption (Table 4) indicate that there is no significant dif- 
ference $(\mathrm{p}>0.005)$ between the different treatments. However, the most important levels of nitrogen and phosphorus in the dry matter of seedlings were recorded with inoculation of $P$. putida, $S$. marcescens, while calcium and magnesium assimilation was improved with treatment $P$. cichorii and $P$. cichorii $+50 \%$ NPK. The higher amount of $\mathrm{N}$ and $\mathrm{P}$ detected in the dry matter of inoculated plants by $P$. putida, $S$. marcescens as well as growth promotion and yield may be attributed to the bacterial-assisted growth enhancement phenomenon [58]. It has been previously show that bacterial able to mediate the acquisition of nitrogen from the air and delivering it to the plant may be used as bio-fertilizer to improve crop productivity and reduce synthetic nitrogen fertilizer application [59]. Overall, maize plants inoculated in our study showed relatively low levels of nutrients. These results could be explained on the one hand by the genetic profile of the strains tested. The same observations were made by [60], who reported that the nitrogen content of the plant depends on the nitrogenase activity of the nitrogen fixing bacteria contained in the maize rhizosphere. In their studies, Berger et al. [61] argued that rhizobacteria PGPR use one or more mechanisms to improve plant growth, yield and health. The good level of yield in biomass and seed corn obtained in our trials at the level of seedlings inoculated with rhizobacteria, despite the reduction in the dose of mineral fertilizers, can be explained by several factors. Indeed, the majority of the strains being studied were reported as isolates promoting the growth of plants with multiple PGPR attributes that could significantly influence crop growth and yield [62]. Auxin production has been proposed as a major mechanism in stimulating the direct growth of plants in some studies [63] [64]. The positive effect of observed PGPR may also be related to the ability of our strains to produce antifungal metabolites such as siderophores, hydrolytic enzymes and antibiotics [65] [66]. Inoculation of field crops with compatible strains showed better results than single inoculation [67]. The improving effect of seed inoculation with bacterial consortia on growth, nutrient content and grain yield of maize and rice plant was reported by several researchers [48] [68]. In the current study, (S. marcescens + P. putida + $50 \% \mathrm{NKP}$ ) treatment did not express a high stimulation capacity for certain parameters evaluated. The low performance recorded for this co-inoculation would be explained by the choice of microorganisms used. Rice et al. [69] had indicated that competition phenomena and antagonisms can be established between inoculated strains, and in some cases lead to reducing their intrinsic capacity.

\section{Conclusion}

The results of current study had clearly shown the power of our PGPRs on maize growth and productivity under field condition. Out of the strains tested, inoculation of $S$. marcescens and P. putida stimulates the most important levels of nitrogen and phosphorus in the dry matter of seedlings and better improvement of maize grain yield. The combined use of $S$. marcescens and $P$. putida and recommended half-dose of NPK was more economical in terms of crop yield, and it was also a sustainable crop production technology. Thus, this approach could 
reduce over application of NPK fertilizer for the profit of farmers in northern Benin and should be an environmental friendly practice.

\section{Acknowledgements}

This work was financially supported by "Centre National de Spécialisation sur le Maïs (CNS-Maïs)" and the "Fond National pour la Recherche Scientifique et de l'Innovation Technologique (FNRSIT) of the Benin government". The authors sincerely thank Mr AYETITON SOUMANOU Mashoudi, technician at North Agricultural Research Centre (CRA-Nord) for his valuable assistance during executing the experiment.

\section{Conflicts of Interest}

The authors declare that the research was conducted in the absence of any commercial or financial relationships that could be construed as a potential conflict of interest.

\section{References}

[1] Naitormmbaide, M., Djondang, K., Mama, V.J. and Koussou, M. (2015) Criblage de quelques variétés de maïs (Zea mays L.) pour la résistance au Striga hermonthica (Del) Benth dans les savanes tchadiennes. Journal of Animal \& Plant Sciences, 24 3722-3732. http://www.m.elewa.org/JAPS

[2] Johnston-Monje, D. and Raizada, M.N. (2011) Conservation and Diversity of Seed Associated Endophytes in Zea across Boundaries of Evolution, Ethnography and Ecology. PLoS ONE, 6, e20396. https://doi.org/10.1371/journal.pone.0020396

[3] WFP (2014) Global Analysis of Vulnerability Food Security and Nutrition (AGVSAN). 146.

[4] Toléba-Séidou, M., Biaou, G., Saïdou, A. and Zannou, A. (2015) Fonctionnement de la filière maïs au Bénin. Cahiers du CBRST, Cotonou (Bénin), 1, 73-35-73.

[5] MAEP (Benin Ministry of Agriculture, Livestock and Fisheries) (2017) MAEP Plan Stratégique de Développement du Secteur Agricole (PSDSA) 2025 et Plan National d'Investissements Agricoles et de Sécurité Alimentaire et Nutritionnelle PNIASAN 2017-2021. Cotonou NB.

[6] INRAB (2016) Fertilité des sols au Bénin. 4ème Trimestre, Dépôt légal $\mathrm{N}^{\circ} 9841 \mathrm{du}$ 05/12/2017, Bibliothèque National du Bénin, 2.

[7] Hengl, T., Leenaars, J.G.B., Shepherd, K.D., Walsh, M.G., Heuvelink, G.B.M., Mamo, T., Tilahun, H., Berkhout, E., Cooper, M., Fegraus, E., et al. (2017) Soil Nutrient Maps of Sub-Saharan Africa: Assessment of Soil Nutrient Content at $250 \mathrm{~m}$ Spatial Resolution Using Machine Learning. Nutrient Cycling Agroecosystems, 109, 77-102. https://doi.org/10.1007/s10705-017-9870-x

[8] Gupta, G., Parihar, S.S., Ahirwar, N.K., Snehi, S.K. and Singh, V. (2015) Plant Growth Promoting Rhizobacteria (PGPR): Current and Future Prospects for Development of Sustainable Agriculture. Journal of Microbial and Biochemical Technology, 7, 96-102.

[9] Sanchez, P.A., Shepherd, K.D., Soule, M.J., Place, F.M., Mokwunye, A.U., Buresh, R.J., Kwesiga, F.R., Izac, A.N., Ndiritu, C.G. and Woomer, P.L. (1997) Soil Fertility 
Replenishment in Africa: An Investment in Natural Resource Capital. In: Buresh, R.J., Sanchez, P.A. and Calhoun, F., Eds., Replenishing Soil fertility in Africa, SSSA Special Publication, Soil Science Society of American and American Society of Agronomy, Madison, 43-121.

[10] Mongana, J.C. (2014) Détermination du moment d'application de Tithonia diversifolia et son évaluation agro économique sous culture de haricot (Phaseolus Vulgaris L.).

[11] INSAE (Institut National de la Statistique et de l'Analyse Economique) (2013) Interim Results of the Rgph 4. Cotonou.

[12] Timmusk, S., Behers, L., Muthoni, J., Muraya, A. and Aronsson, A.C. (2017) Perspectives and Challenges of Microbial Application for Crop Improvement. Frontier Plant Science, 8, 49. https://doi.org/10.3389/fpls.2017.00049

[13] Kloepper, J.W., Lifshitz, R. and Zablotowicz, R.M. (1989) Free-Living Bacterial Inocula for Enhancing Crop Productivity. Trends in Biotechnology, 7, 39-44. https://doi.org/10.1016/0167-7799(89)90057-7

[14] Cherif, H., Neifar, M., Chouchane, H., Soussi, A., Hamdi, C. and Guesmi, A. (2017) Extremophile Diversity and Biotechnological Potential from Desert Environments and Saline Systems of Southern Tunisia. In: Ravi, V., Durvasula, D. and Subba Rao, V., Eds., Extremophiles: From Biology to Biotechnology, CRC Publishers, Boca Raton, 33-64. https://doi.org/10.1201/9781315154695-3

[15] Van der Heijden, M.G., Bardgett, R.D. and van Straalen, N.M. (2008) The Unseen Majority: Soil Microbes as Drivers of Plant Diversity and Productivity in Terrestrial Ecosystems. Ecology Letters, 11, 296-310. https://doi.org/10.1111/j.1461-0248.2007.01139.x

[16] Bhardwaj, D., Ansari, M.W., Sahoo, R.K. and Tuteja, N. (2014) Biofertilizers Function as Key Player in Sustainable Agriculture by Improving Soil Fertility, Plant Tolerance and Crop Productivity. Microbial Cell Factories, 3, 66. https://doi.org/10.1186/1475-2859-13-66

[17] Choudhary, D.K. and Varma, A. (2016) Microbial-Mediated Induced Systemic Resistance in Plants. Springer Science + Business Media, Singapore. https://doi.org/10.1007/978-981-10-0388-2

[18] Drogue, B., Doré, H., Borland, S., Wisniewski-Dyé, F. and Prigent-Combaret, C. (2012) Which Specificity in Cooperation between Phytostimulating Rhizobacteria and Plants. Research in Microbiology, 163, 500-510. https://doi.org/10.1016/j.resmic.2012.08.006

[19] Matteoli, F.P., Passarelli-Araujoa, H., Reisb, R.J.A., Rochab, O.L., Souzac, M.E., Aravindd, L., Olivaresb, L.F. and Venancio, M.T. (2018) Genome Sequencing and Assessment of Plant Growth-Promoting Properties of a Serratia marcescens Strain Isolated from Vermicompost. BMC Genomics, 19, 750.

https://doi.org/10.1186/s12864-018-5130-y

[20] Cakmakci, R., Dönmez, M.F. and Erdoğan, Ü. (2007) The Effect of Plant Growth Promoting Rhizobacteria on Barley Seedling Growth, Nutrient Uptake, Some Soil Properties, and Bacterial Counts. Turkey Journal of Agriculture and Forestry, 31, 189-199.

[21] Alori, E.T., Glick, B.R. and Babalola, O.O. (2017) Microbial Phosphorus Solubilization and Its Potential for Use in Sustainable Agriculture. Frontier Microbiology, 8, 971. https://doi.org/10.3389/fmicb.2017.00971

[22] Amogou, O., Dagbénonbakin, G., Agbodjato, N.A., Noumavo, P.A., Salami, H.A., 
Valère, S., Ricardos, A.M., Sylvestre, A.A., Djihal, K.F.A., Adjanohoun, A. and Baba-Moussa, L. (2018) Influence of Isolated PGPR Rhizobacteria in Central and Northern Benin on Maize Germination and Greenhouse Growth. American Journal of Plant Sciences, 9, 2775-2793. https://doi.org/10.4236/ajps.2018.913201

[23] Agbodjato, N.A., Noumavo, P.A., Baba-Moussa, F., Salami, H.A., Sina, H., Sèzan, A., Bankolé, H., Adjanohoun, A. and Baba-Moussa, L. (2015) Characterization of Potential Plant Growth Promoting Rhizobacteria Isolated from Maize (Zea mays L.) in Central and Northern Benin (West Africa). Applied and Environmental Soil Science, 2015, Article ID: 901656. https://doi.org/10.1155/2015/901656

[24] MAEP (Benin Ministry of Agriculture, Livestock and Fisheries) (2016) Catalogue Béninois des Espèces et Variétés végétales (CaBEV), 2016. 4ème trimestre, INRAB/DPVPPAAO/ProCAD/MAEP \& CORAF/WAAPP, Dépôt légal Nº $8982 \mathrm{du}$ 21 octobre 2016, Bibliothèque Nationale (BN) du Bénin, 339.

[25] CRA-Nord (2007) Rapport Annuel. Institut National des Recherches Agricoles du Bénin, Centre de Recherche Agricole Nord Ina, Bénin.

[26] Hillebrand, W.F., Lundell, G.E.F., Bright, H.A. and Hoffman, J.I. (1953) Applied Inorganic Analysis. 2nd Edition, John Wiley and Sons, Inc., New York.

[27] Bray, R.I. and Kurtz, L.T. (1945) Determination of Total Organic, and Available Forms of Phosphorus in Soils. Soil Sciences, 59, 39-45. https://doi.org/10.1097/00010694-194501000-00006

[28] Walkley, A. and Black, I.A. (1934) An Examination Method of the Det Jareff and a Proposed Modification of the Chromic Acid Titration Method. Soil Science, 37, 29-38. https://doi.org/10.1097/00010694-193401000-00003

[29] McLean, E.O. (1982) Soil pH and Lime Requirement. In: Page, A.L., Miller, R.H. and Keeney, D.R., Eds., Methods of Soil Analysis, Part 2, Chemical and Microbiological Properties-Agronomy No. 9, ASA-SSSA, Madison, 199-224.

[30] Guiraud, J. and Galzy, P. (1994) Contrôle Microbiologique dans les Industries Agroalimentaires (2ème eds) Doin.

[31] Wahyudi, A.T., Astuti, R.P., Widyawati, A., Meryandini, A. and Nawangsih, A.A. (2011) Characterization of Bacillus sp. Strains Isolated from Rhizosphere of Soybean Plants for Their Use as Potential Plant Growth for Promoting Rhizobacteria. Journal of Microbiology and Antimicrobial, 3, 34-40.

[32] Aparna, Y. and Sarada, J. (2012) Molecular Characterization and Phylogenetic Analysis of Serratia sp-YAJS: An Extracellular Dnase Producer Isolated from Rhizosphere Soil.

[33] Govindappa, M.R.V., Ravishankar, S. and Lokesh (2011) Screening of Pseudomonas Fluorescens Isolates for Biological Control of Macrophomina phaseolina Root-Rot of Safflower. African Journal of Agricultural Research, 6, 6256-6266. https://doi.org/10.5897/AJAR10.1017

[34] Ruget, F., Bonhomme, R. and Chartier, M. (1996) Estimation simple de la surface foliaire de plantes de maïs en croissance. Agronomie, 16, 553-562.

https://doi.org/10.1051/agro:19960903

[35] Valdés, E.M.F., González, E.C., Serrano, M.M., Labrada, H.R., Báez, E.M., Hernández, F.G. and Hernández, F.A. (2013) Experiencias obtenidas en el desarrollo participativo de híbridos lineales simples de maíz en condiciónes de bajos insumos agrícolas. Cultivos Tropicales, 34, 61-69.

[36] Olsen, S.R. and Sommers, L.E. (1982) Phosphorus. In: Page, A.L., Miller, R.H. and Keeney, D.R., Eds., Methods of Soil Analysis, Part 2, Chemical and Microbiological 
Properties-Agronomy No. 9, ASA-SSSA, Madison, 403-427.

[37] Sertsu, S. and Bekele, T. (2000) Procedures for Soil and Plant Analysis. Ethiopian Agricultural Research Organization, Addis Ababa.

[38] Thomas, G.W. (1982) Exchangeable Cation. In: Page, A.L., Miller, R.H. and Keeney, D.R., Eds., Methods of Soil Analysis, Part 2, Chemical and Microbiological Properties-Agronomy No. 9, ASA-SSSA, Madison, 154-157.

[39] George, T.S., Gregory, P.J. and Wood, M. (2002) Phosphatase Activity and Organic Acids in the Rhizosphere of Potential Agroforesty Species and Maize. Soil Biology and Biochemistry, 34, 1487-1494. https://doi.org/10.1016/S0038-0717(02)00093-7

[40] Martínez-Viveros, O.M.A., Jorquera, D.E., Crowley, G. and Gajardo, M.L. (2010) Mechanisms and Practical Considerations Involved in Plant Growth Promotion by Rhizobacteria. Journal of Soil Science and Plant Nutrition, 10, 293-319. https://doi.org/10.4067/S0718-95162010000100006

[41] Sanchez, P.A. and Jama, B.A. (2002) Soil Fertility Replenishment Takes off in East and Southern Africa. International Centre for Research in Agro Forestry, Nairobi, 352.

[42] Wezel, A., Rajot, J.L. and Herbrig, C. (2000) Influence of Shrubs on Soil Characteristics and Their Function in Sahelian Agro-Ecosystems in Semi-Arid Niger. Journal of Arid Environments, 44, 383-398. https://doi.org/10.1006/jare.1999.0609

[43] Igué, A.M., Saïdou, A., Adjanohoun, A., Ezui, G., Attiogbé, P., Kpagbin, G., GotoechanHodonou, H., Youl, S., Pare, T., Balogoun, I., Ouedraogo, J., Dossa, E., Mando, A. and Sogbedji, J.M. (2013) Evaluation de la fertilité des sols au sud et centre du Bénin. Bulletin de la Recherche Agronomique du Bénin (BRAB) Numéro Spécial Fertilité du maïs Janvier.s.

[44] Kaur, G. and Reddy, M.S. (2015) Effects of Phosphate-Solubilizing Bacteria, Rock Phosphate and Chemical Fertilizers on Maize-Wheat Cropping Cycle and Economics. Pedosphere, 25, 428-437. https://doi.org/10.1016/S1002-0160(15)30010-2

[45] Chakraborty, U., Chakraborty, B.N. and Chakraborty, A.P. (2010) Influence of Serratia marcescens TRS-1 on Growth Promotion and Induction of Resistance in Camellia sinensis against Fomes lamaoensis. Journal of Plant Interactions, 5, 261-272. https://doi.org/10.1080/17429140903551738

[46] Ashrafi, V. and Naser, M. (2011) Influence of Different Plant Densities and Plant Growth Promoting Rhizobacteria (Pgpr) on Yield and Yield Attributes of Corn (Zea maize L.). Recent Research in Science and Technology, 3, 63-66.

[47] Ahemad, M. and Kiber, M. (2014) Mechanisms and Applications of Plant Growth Promoting Rhizobacteria: Current Perspective. Journal of King Saud University: Science, 26, 1-20. https://doi.org/10.1016/j.jksus.2013.05.001

[48] Akhtar, N., Naveed, M., Khalid, M., Ahmad, N., Rizwan, M. and Siddique, S. (2018) Effect of Bacterial Consortia on Growth and Yield of Maize Grown in Fusarium Infested Soil. Soil Environment, 37, 35-44. https://doi.org/10.25252/SE/18/872

[49] Moustaine, M., Elkahkahi, R., Benbouazza, A., Benkirane, R. and Achbani, E.H. (2017) Effect of Plant Growth Promoting Rhizobacterial (PGPR) Inoculation on Growth in Tomato (Solanum lycopersicum L.) and Characterization for Direct PGP Abilities in Morocco. International Journal of Environment, Agriculture and Biotechnology, 2, 590-596. https://doi.org/10.22161/ijeab/2.2.5

[50] Duponnois, R., Founoune, H., Masse, D. and Pontanier, R. (2005) Inoculation of 
Acacia Endophytes in Zea across Boundaries of Evolution, Ethnography and Ecology.

[51] Biaou, G. and Gnimadi, C. (2012) Étude socio-économique de synthèse des villages de Founougo_A, Founougo_B et Kanderou. Rapport provisoire pour le "Projet d'Appui à l'Opérationnalisation des Villages du Millénaire" (PVM). 150.

[52] Isfahani, F.M. and Besharati, H. (2012) Effect of Biofertilizers on Yield and Yield Components of Cucumber. Journal of Biology and Earth Sciences, 2, 83-92.

[53] Mosimann, C., Oberhänsli, T., Ziegler, D., Nassal, D., Kandeler, E., Boller, T., Mäder, P. and Thonar, C. (2017) Tracing of Two Pseudomonas Strains in the Root and Rhizoplane of Maize, as Related to Their Plant Growth-Promoting Effect in Contrasting Soils. Frontiere in Microbiology, 7, 2150.

https://doi.org/10.3389/fmicb.2016.02150

[54] Zabihi, H., Savaghebi, G., Khavazi, K., Ganjali, A. and Miransari, M. (2011) Pseudomonas Bacteria and Phosphorous Fertilization, Affecting Wheat (Triticum aestivum L.) Yield and P Uptake under Greenhouse and Field Conditions. Acta Physiologiae Plantarum, 33, 145-152. https://doi.org/10.1007/s11738-010-0531-9

[55] Lavakush, Y.J. and Verma, J.P. (2012) Isolation and Characterization of Effective Plant Growth Promoting Rhizobacteria from Rice Rhizosphere of Indian Soil. Asian Journal Biological Science, 5, 294-303. https://doi.org/10.3923/ajbs.2012.294.303

[56] Suslow, T.V. and Schroth, M.N. (1982) Rhizobacteria of Sugarbeet: Effects of Seed Application and Root Colonization on Yield. Phytopathology, 72, 199-206. https://doi.org/10.1094/Phyto-72-199

[57] Biari, A., Gholami, A. and Rahmani, H.A. (2008) Growth Promotion and Enhanced Nutrient Uptake of Maize (Zea mays L.) by Application of Plant Growth Promoting Rhizobacteria in Arid Region of Iran. Journal of biological Sciences, 8, 1015-1020. https://doi.org/10.3923/jbs.2008.1015.1020

[58] Deepa, C.K., Dastager, S.G. and Pandey, A. (2010) Isolation and Characterization of Plant Growth Promoting Bacteria from Non-Rhizospheric Soil and Their Effect on Cowpea (Vigna unguiculata (L.) Walp.) Seedling Growth. World Journal Microbiology and Biotechnology, 26, 1233-1240. https://doi.org/10.1007/s11274-009-0293-y

[59] Riberiro, C.M. and Cardoso, E.J. (2012) Isolation, Selection and Characterization of Root Associated Growth Promoting Bacteria in Brazil Pine (Araucaria angustifolia). Microbiology Research, 167, 69-78. https://doi.org/10.1016/j.micres.2011.03.003

[60] Bouffaud, M.L., Renoud, S., Moënne-Loccoz, Y. and Muller, D. (2016) Is Plant Evolutionary History Impacting Recruitment of Diazotrophs and nifH Expression in the Rhizosphere? Scientific Reports, 6, Article No. 21690.

https://doi.org/10.1038/srep21690

[61] Berger, B., Wiesner, M., Brock, A.K., Schreiner, M. and Ruppel, S. (2015) K. radicincitans. A Beneficial Bacteria That Promotes Radish Growth under Field Conditions. Agronomy for Sustainable Development, 35, 1521-1528. https://doi.org/10.1007/s13593-015-0324-Z

[62] Agbodjato, N.A., Amogou, O., Noumavo, P.A., Dagbenonbakin, G., Hafiz, A.S., Kamirou, R., Alladé, A.M., Adebayo, O., Baba-Moussa, F., Adjanohoun, A. and Ba-ba-Moussa, L. (2018) Biofertilising, Plant-Stimulating and Biocontrol Potentials of Isolated PGPR Rhizobacteria in Central and Northern Benin. African Journal of Microbiology Research, 12, 664-672. https://doi.org/10.5897/AJMR2018.8916

[63] Khalid, A., Arshad, M. and Zahir, Z. (2004) Screening Plant Growth-Promoting 
Rhizobacteria for Improving Growth and Yield of Wheat. Journal of Applied Microbiology, 96, 473-480. https://doi.org/10.1046/j.1365-2672.2003.02161.x

[64] Joshi, B.H. and Joshi, P.P. (2017) Screening and Characterization of Multi-Trait Plant Growth Promoting Bacteria Associated with Sugarcane for Their Prospects as Bioinoculants. International Journal of Current Microbiology and Applied Sciences, 6, 240-252. https://doi.org/10.20546/ijcmas.2017.604.028

[65] Kilian, M., Steiner, U., Krebs, B., Junge, H., Schmiedeknecht, G. and Hain, R. (2000) FZB24 ${ }^{\oplus}$ Bacillus Subtilis-Mode of Action of a Microbial Agent Enhancing Plant Vitality. Pflanzenschutz-Nachrichten Bayer, 1, 72-93.

[66] Chowdhury, P.S., Hartmann, A., Gao, X. and Borriss, R. (2015) Biocontrol Mechanism by Root-Associated Bacillus amyloliquefaciens FZB42-A Review. Frontier in Microbiology, 6, 780. https://doi.org/10.3389/fmicb.2015.00780

[67] Figueiredo, M.V.B., Seldin, L.F.F., de Araujo and Mariano, R.L.R. (2010) Plant Growth Promoting Rhizobacteria: Fundamentals and Applications. In: Maheshwari, D.K., Ed., Plant Growth and Health Promoting Bacteria, Springer, Berlin, 21-43. https://doi.org/10.1007/978-3-642-13612-2_2

[68] Ines García de Salamone, I.E., Funes, J.M., Di Salvo, L.P., Escobar-Ortega, J.S., D'Auria, F., Ferrando, L. and Fernandez-Scavino, A. (2012) Inoculation of Paddy Rice with Azospirillum brasilense and Pseudomonas fluorescens. Impact of Plant Genotypes on Rhizosphere Microbial Communities and Field Crop Production. Applied Soil Ecology, 61, 196-204. https://doi.org/10.1016/j.apsoil.2011.12.012

[69] Rice, W.A., Lupwayi, N.Z., Olsen, P.E., Schlechte, D. and Gleddie, S.C. (2000) Field Evaluation of Dual Inoculation of Alfalfa with Sinorhizobium meliloti and Penicillium bilaii. Canadian Journal of Plant Science, 80, 303-308. https://doi.org/10.4141/P99-055 